\title{
PENGARUH KUALITAS PRODUK DAN HARGA TERHADAP MINAT BELI LEMBUR BATIK
}

\author{
Feby Febrian \\ Universitas Winayamukti \\ Febrian9009@yahoo.com
}

\begin{abstract}
Abstrak - Setiap perusahaan harus mampu menarik konsumen dengan menawarkan produk yang berkualitas, penetapan harga yang tepat sesuai dengan kebutuhan pasar yang dapat mendorong pertumbuhan minat beli konsumen terhadap suatu produk. Penelitian ini bertujuan untuk mengetahui apakah kualitas produk dan harga berpengaruh terhadap minat beli untuk membeli pakaian batik. Penelitian ini merupakan penelitian descriptive dan verifikatif dengan menggunakan analisis jalur (Path Analysis), , dimana populasi responden adalah semua konsumen batik lembur sebanyak 500 orang dengan sampel 84 orang responden dengan software SPSS 21. Dari hasil tanggapan responden yang telah terdistribusi maka secara simultan hasil pengujian menunjukkan bahwa kualitas produk dan harga mempengaruhi minat beli dengan pengaruh kualitas produk sebesar 0,577 dan signifikan terhadap harga 0,263 dan secara simultan pengaruh kedua variabel pada minat beli 0,354 . Dari hasil penelitian secara parsial mengetahui kualitas produk yang lebih dominan berpengaruh pada minat beli dibandingkan harga.
\end{abstract}

Kata kunci: Kualitas Produk, Harga dan Minat Beli.

Abstract : Every company must be able to attract consumers by offering quality products, fixing the right price according to market needs that can encourage the growth of consumer buying interest in a product. This study aims to determine whether product quality and prices affect buying interest to buy batik clothing. This study is a descriptive and verivative study using Path Analysis, where the population of respondents is all consumers of batik lembur as many as 500 people with a sample of 84 respondents with SPSS 21 software. From the results of responses of respondents who have been distributed then the results of the test are simultaneous shows that product quality and price affect buying interest with the effect of product quality of 0.577 and price-significant of 0.263 and simultaneously the influence of both variables on buying interest is 0.354 . From the results of the study partially knowing the quality of products that are more dominantly influential on buying interest compared to prices.

Keywords: Product Quality, Price and Buy Interest. 


\section{PENDAHULUAN}

Pertumbuhan ekonomi global di tahun 2017 ini telah kembali ke jalur yang seharusnya setelah di tempa krisis finansial global pada tahun 2008. Risiko atas pertumbuhan geopolitik yang terus mengalami peningkatan dari tahun ke tahunnya yaitu dimana implikasi terhadap fluktuasi mata uang euro sangat signifikan mempengaruhi laju pertumbuhan ekonomi dunia. Sejalan dengan hal tersebut hal ini akan memberikan sentimen positif terhadap laju pertumbuhan ekonomi global secara keseluruhan. Tingkat pertumbuhan perekonomian dunia telah kembali ke level yang belum pernah dilihat lagi sejak krisis ekonomi global dan diprediksi memiliki momentum positif berlanjut di kuartal II 2017. Penguatan normalisasi kebijakan moneter yang dilakukan oleh bank central di seluruh dunia seperti halnya The Fed, ECB, Bank Indonesia, Bank Sentral China, DII, dilakukan semata-mata untuk melakukan pengetatan tanpa harus menghalangi pertumbuhan. Hal ini menjadi sebuah sandaran regulasi dalam memacu pertumbuhan ekonomi di seluruh dunia, khususnya di Indonesia tanpa harus menciptakan rasa ketakutan di sektor pasar finansial. Ditengah kebijakan ekonomi AS yang penuh ketidakpastian, Amerika menerapkan sistem perekonomian yang penuh dengan proteksionis dan kemudahan serta kelonggaran dalam aspek finansial pertumbuhan ekonominya. Tentunya ini menjadi bahan pertimbangan bagi pemerintah Indonesia dalam menggenjot basis ekspor guna meningkatkan pendapatan asli negara dalam rangka menciptakan kemudahan dalam menggerakan pertubuhan ekonomi diberbagai wilayah Indonesia. Sejak tahun 2014 hingga saat ini beberapa paket kebijakan telah diluncurkan oleh pemerintah indonesia dalam menggiatkan dan menggerakan roda perputaran ekonomi agar stabilitas pertumbuhan terus terjaga. Persaingan antara pasar domestik dan pasar ekspor sangat tajam mengakibatkan iklim daya beli masyarakat menjadi terbatas. Keadaan ekonomi dalam era globalisasi dewasa ini membuat persaingan bisnis menjadi semakin tajam, baik pasar domestik maupun pasar global.

Situasi dan keadaan seperti ini membuat para produsen dan konsumen akan mampu mengakses informasi obyektif mengenai potensi pasar yang dapat dikembangkan sebagai basis pertumbuhan dan perkembangan ekonomi suatu daerah atau kawasan. Para produsen atau perusahaanperusahaan bersaing semaksimal mungkin dalam melayani setiap kebutuhan konsumennya. Semakin meningkatnya kebutuhan dan permintaan konsumen maka menyebabkan melahirkan perusahaanperusahaan baru yang bertujuan untuk memenuhi kebutuhan atau keinginan konsumen tersebut.

Walaupun konsumen tetap ada namun daya beli mereka semakin terbatas, akibatnya konsumen menjadi semakin kritis dalam melakukan pembelian atas produk yang mereka butuhkan, pemilihan dan penetapan harga jual yang sesuai dengan kebutuhan pasar serta animo pertumbuhan minat beli yang terbatas. Oleh karena hal tersebut maka kualitas produk harus memiliki nilai lebih dan berbeda dari produk lainnya yang di tawarkan oleh penjual kepada pembeli seperti halnya jaminan kualitas, model, desain dan sikap suka yang dimiliki pembeli tersebut. Meskipun ada beberapa faktor lainya seperti bahan, proses produksi, tingkat kesesuaian, pengenalan, kecocokan, daya tahan dan harga produk semua itu merupakan 
unsur-unsur pelengkap yang saling berkaitan satu sama lainnya. Penetapan harga yang tepat sesuai dengan kebutuhan pasar harus peka dan fleksibel dalam memahami keadaan dan perkembangan yang ada seperti bahwa harga sesuai dengan kepentingan , perkembangan dan permintaan pasar serta memiliki daya saing yang kuat dimana hal ini dapat menumbuhkan minat beli seseorang terhadap suatu produk. Menurut Susanti (2017:23) kualitas merupakan salah satu syarat yang menumbuhkan minat beli dari konsumen. Menurut Susanti (2017:230) produk dapat dianggap berkualitas jika dapat memenuhi harapan pelanggan.

Menurut Zakaria dan Suwitho (2017:2) Harga menjadi nilai agregat dari semua hal yang diberikan produsen terhadap pelanggan dalam mendapatkan keuntungan memiliki atau menggunakan suatu produk atau jasa. Minat Beli sendiri adalah perasaan atau keputusan yang berasal dari keterkaitannya dengan sesuatu antara lain minat untuk membeli, melakukan penawaran, melakukan transaksi dan minat untuk melakukan kunjungan. Menurut Faradiba (2013:2) minat beli ulang tercipta karena konsumen merasa kualitas produk dan kualitas pelayanan yang di berikan sesai apa yang mereka harapkan sehingga konsumen akan berniat membeli produk kita di waktu selanjutnya.

Dalam keadaan tersebut mendorong setiap perusahaan untuk lebih bekerja secara profesional agar tetap dapat bersaing dan bertahan, setiap perusahaan harus mampu menarik konsumen dengan menawarkan produk yang berkualitas, penetapan harga yang tepat sesuai dengan kebutuhan pasar yang dapat mendorong pertumbuhan minat beli konsumen terhadap suatu produk.
Tujuan penelitian sesuai dengan identifikasi masalah adalah untuk mengetahui :

1. Kualitas Produk pada Lembur Batik ?

2. Harga pada Lembur Batik ?

3. Seberapa besar Pengaruh Kualitas Produk dan Harga terhadap Minat Beli pada Lembur Batik?

\section{KAJIAN LITERATUR}

Konsep pemasaran didasari oleh gagasan untuk memuaskan kebutuhan pelanggan melalui produk dan hal-hal yang berhubungan dengan menciptakan, menghantarkan, dan akhirnya mengonsumsinya, Philip Kotler (2009:20).

"Marketing management is the analysis, planning, implementation, and control of program designed to create, build, ang maintain beneficial exchanges with target buyers for the purpose of achieving organizational objectives". Philip Kotler dan Amstrong dalam Buchari Alma (2007:130).

Konsep produk berpendapat bahwa konsumen menyukai produk yang menawarkan kualitas, kinerja atau fitur inovatif terbaik. Manajer dari organisasi ini berfokus untuk membuat produk yang unggul dan senantiasa memutakhirkannya. Phillip Kotler (2009:19).

Atributes,W.J. Stanton dalam Buchari Alma (2007:139) A product is a set of tengible atributes, including packaging, color, price, manufacturer's prestige, and manufacturer's and retailer, which the buyer may accept as offering want satisfaction.

Produk ialah seperangkat atribut baik berwujud maupun tidak berwujud, termasuk didalam-Nya masalah warna, 
harga, nama baik pabrik, nama baik toko yang menjual (pengecer) dan pelayanan pabrik serta pelayanan pengecer, yang diterima oleh pembeli guna memuaskan keinginannya

Kualitas produk merupakan atribut penting bagi konsumen ketika membahas konsumen ritel (Noad dan Rogers, 2008) dalam S.T. Wang Edward, (2013).

Kualitas produk merupakan pemahaman bahwa produk yang ditawarkan oleh penjual mempunyai nilai jual lebih yang tidak dimiliki oleh produk pesaing. Oleh karena itu perusahaan berusaha memfokuskan pada kualitas produk dan membandingkannya dengan produk yang ditawarkan oleh perusahaan pesaing. Akan tetapi, suatu produk dengan penampilan terbaik tampilan lebih baik bukanlah merupakan produk dengan kualitas tertinggi jika tampilannya bukanlah yang dibutuhkan dan diinginkan oleh pasar.

Menurut Kharisma, Arifin dan Wilopo (2014:92) Kualitas produk merupakan aspek penting dalam strategi pemasaran, dengan kondisi saat ini produk berkualitas tentunya nilai yang dimilikinya lebih unggul jika dibandingkan pada produk lain.

Menurut Philip Kotler (2007:94) menjelaskan salah satu nilai utama yang diharapkan oleh pelanggan dari pemasok adalah mutu produk dan jasa yang tinggi. Maka dari pernyataan tersebut dapat dinyatakan bahwa mutu atau kualitas produk dapat mempengaruhi konsumen dalam memutuskan untuk memperoleh produk tersebut.

Menurut Rosadi dalam Kharisma, Arifin dan Wilopo (2014:95) menjelaskan bahwa suatu produk yang akan dibuat atau di produksi harus sesuai dengan kebutuhan konsumen, serta produk tersebut harus mencerminkan kualitas yang baik sehingga dapat memberikan daya tarik bagi konsumen.

Kualitas produk harus memiliki nilai lebih dan berbeda dari produk lainnya yang di tawarkan oleh penjual kepada pembeli seperti halnya jaminan kualitas, model, desain dan sikap suka yang dimiliki pembeli tersebut. Meskipun ada beberapa faktor lainya seperti bahan, proses produksi, tingkat kesesuaian, pengenalan, kecocokan , daya tahan dan harga produk semua itu merupakan unsur-unsur pelengkap yang saling berkaitan satu sama lainnya.

Harga merupakan satu-satunya elemen bauran pemasaran yang menghasilkan pendapatan. Harga juga merupakan elemen bauran pemasaran yang fleksibel. Harga dapat diubah dengan cepat tidak seperti produk dan distribusi. Penetapan dan persaingan harga merupakan masalah nomor satu yang dihadapi perusahaan. Banyak perusahaan yang tidak menangani penetapan harga yang baik, Philip Kotler (2007:519).

Harga sebagai harga normatif atau harga yang diharapkan sebagai harga berbasis memori dan kebutuhan untuk memahami masalah yang terjadi secara berlebihan (Mazumdar et al., 2005, p. 99) dalam (Ben Lowe Fanny Chan Fong Yee Pamela Yeow , (2014)).

Harga adalah sejumlah uang sebagai alat tukar untuk memperoleh produk atau jasa. Harga dapat juga dikatakan penentuan nilai suatu produk dibenak konsumen, Djaslim Saladin (2007:95). Kebijakan harga adalah keputusan-keputusan mengenai harga yang di tetapkan oleh manajemen, Djaslim Saladin (2007:95).

Menurut Ningtias dan Budiarti (2017: 3) Harga adalah nilai tukar yang disamakan dengan uang atau barang lain untuk manfaat yang diperoleh dari barang atau jasa dan sejumlah uang 
yang konsumen bayar untuk produk tertentu.

Tiga jenis utama dari situasi pembelian (atau kelas) yang sejauh ini diidentifikasi, pembelian kembali langsung, pembelian ulang yang dimodifikasi, dan pembelian tugas baru, masing-masing melibatkan proses keputusan yang berbeda dan tindakan, dengan implikasi serius bagi pembeli dan penjual (Robinson et al., 1967) dalam Leonidas C. Leonidou, (2005),"

Minat konsumen meningkat dengan kesadaran, peningkatan minat bahkan lebih tinggi ketika kesadaran digabungkan dengan percobaan. Minat dalam suatu layanan adalah fungsi waktu dalam siklus konsumsi layanan secara keseluruhan. Artinya, minat dalam layanan yang ditawarkan secara positif terkait dengan minat keseluruhan dalam penyediaan layanan Audhesh $\mathrm{K}$. Paswan, Gopala Ganesh (2003).

Pengertian minat beli konsumen adalah sesuatu yang timbul setelah menerima rangsangan dari produk yang dilihatnya, dari sana timbul ketertarikan untuk mencoba produk tersebut sampai pada akhirnya timbul keinginan untuk membeli agar dapat dimilikinya. Philip Kotler (2007:205).

Menurut Faradiba (2013:2) minat beli yang muncul menciptakan suatu motivasi yang terus terekam dalam benaknya, yang pada akhirnya ketika seorang konsumen harus memenuhi kebutuhannya akan mengaktualisasikan apa yang ada didalam benaknya itu.

Menurut Faradiba (2013:2) minat beli ulang tercipta karena konsumen merasa kualitas produk dan kualitas pelayanan yang diberikan sesuai apa yang mereka harapkan sehingga konsumen akan berniat untuk membeli produk kita di waktu selanjutnya.

Dengan demikian minat dapat diartikan sebagai kecenderungan sifat yang terorganisir berdasarkan dari pengalaman seseorang, yang mendorong seseorang atau individu untuk mencari keterangan atau faktafakta dari sebuah objek, aktivitas atau kegiatan, pemahaman, skill, tujuan perhatian atau murni ingin mahir dalam hal tertentu. Minat merupakan perasaan yang didapat karena berhubungan dengan sesuatu. Minat terhadap sesuatu itu dipelajari dan dapat mempengaruhi belajar selanjutnya serta mempengaruhi penerimaan minat-minat baru. Jadi, minat terhadap sesuatu merupakan hasil belajar dan cenderung mendukung aktivitas belajar berikutnya. Oleh karena itu minat besar pengaruhnya terhadap aktivitas belajar. Hal tersebut seperti diungkapkan oleh Syaiful Bahri Djamarah (2008:133).

Minat Beli adalah perasaan atau keputusan yang berasal dari keterkaitannya dengan sesuatu antara lain minat untuk membeli, bentuk produk, melakukan penawaran, melakukan transaksi dan minat untuk melakukan kunjungan.

\section{Dimensi Kualitas Produk}

Menurut Tjiptono (2008:56), kualitas mencerminkan semua dimensi penawaran produk yang menghasilkan manfaat (benefits) bagi pelanggan. Kualitas suatu produk baik berupa barang atau jasa ditentukan melalui dimensi-dimensinya. Dimensi kualitas produk menurut Philip Kotler (2006 :188) dimensi-dimensi kualitas produk terdiri dari:

1. Kinerja (performance), yaitu karakteristik operasi pokok dari produk inti

2. Ciri-ciri atau keistimewaan tambahan (features), yaitu karakteristik sekunder atau pelengkap.

3. Kehandalan (reliability), yaitu kemungkinan kecil akan mengalami kerusakan atau gagal pakai. 
4. Kesesuaian dengan spesifikasi (conformance), yaitu sejauh mana karakteristik desain dan operasi memenuhi standar-standar yang telah ditetapkan sebelumnya.

5. Daya tahan (durability), yaitu berkaitan dengan berapa lama produk tersebut dapat terus digunakan.

6. Serviceability, meliputi kecepatan, kompetensi, kenyamanan, mudah direparasi, penanganan keluhan yang memuaskan.

7. Estetika, yaitu daya tarik produk terhadap panca indera.

8. Perceived Quality, yaitu

karakteristik persepsi kualitas.

Berdasarkan dimensi-dimensi diatas, dapat disimpulkan bahwa suatu dimensi kualitas merupakan syarat agar suatu nilai dari produk memungkinkan untuk bisa memuaskan pelanggan sesuai harapan, adapun dimensi kualitas produk meliputi kinerja, estetika, keistimewaan, keandalan, dan juga kesesuaian.

Dalam pengembangan produk, pemasar lebih dahulu harus memilih tingkatan kualitas yang dapat mendukung posisi produk di pasar sasarannya. Tingkat kualitas tidak selalu harus tinggi. Kualitas bisa saja rendah, sedang atau tinggi, sesuai dengan positioning yang diinginkan dan target pasarnya. Selain tingkatan kualitas, kualitas yang tinggi juga dapat berarti konsistensi tingkatan kualitas yang tinggi. Dalam konsisten yang tinggi tersebut kualitas produk berarti kualitas kesesuaian bebas dari kecacatan dan kekonsistenan dalam memberikan tingkatan kualitas yang akan dicapai / dijanjikan. Harga adalah sejumlah uang sebagai alat tukar untuk memperoleh produk atau jasa. Harga dapat juga dikatakan penentuan nilai suatu produk dibenak konsumen, Djaslim Saladin (2007:95).

Menurut Djaslim Saladin 2007:96, Ada beberapa metode penetapan harga antara lain :

a. Cost Oriented

Yaitu penetapan harga yang semata-mata memperhitungkan biaya-biaya dan tidak berorientasi terhadap pasar

b. Demand oriented pricing

Yaitu penentuan harga dengan mempertimbangkan keadaan permintaan, keadaan pasar dan keinginan konsumen.

c. Competitor oriented pricing Yaitu penetapan harga jual yang berorientasi pada pesaing.

Kebijakan harga adalah keputusan-keputusan mengenai harga yang di tetapkan oleh manajemen, Djaslim Saladin (2007:95).

Menurut Fredinand (2002:129) minat beli dapat diidentifikasikan melalui indikator-indikator sebagai berikut :

1. Minat Transaksional, yaitu kecenderungan seseorang untuk membeli produk.

2. Minat Referensial, yaitu kecenderungan seseorang untuk mereferensikan produk kepada orang lain.

3. Minat Preferensial, yaitu minat yang menggambarkan perilaku seseorang yang memiliki preferensi utama pada produk tersebut. Preferensi ini hanya dapat diganti jika terjadi sesuatu dengan produk preferensinya.

4. Minat Eksploratif, yaitu minat ini menggambarkan perilaku seseorang yang selalu mencari informasi mengenai produk yang diminatinya dan mencari informasi untuk mendukung sifat-sifat positif dari produk tersebut. 
Pengertian minat beli konsumen adalah sesuatu yang timbul setelah menerima rangsangan dari produk yang dilihatnya, dari sana timbul ketertarikan untuk mencoba produk tersebut sampai pada akhirnya timbul keinginan untuk membeli agar dapat dimilikinya. (Phillip Kotler, 2007:205).

Menurut Faradiba (2013:2) minat beli yang muncul menciptakan suatu motivasi yang terus terekam dalam benaknya, yang pada akhirnya ketika seorang konsumen harus memenuhi kebutuhannya akan mengaktualisasikan apa yang ada didalam benaknya itu.

Minat Beli adalah perasaan atau keputusan yang berasal dari keterkaitannya dengan sesuatu antara lain minat untuk membeli, bentuk produk, melakukan penawaran, melakukan transaksi dan minat untuk melakukan kunjungan.

Minat beli konsumen adalah sesuatu yang timbul setelah menerima rangsangan dari produk yang dilihatnya, dari sana timbul ketertarikan untuk mencoba produk tersebut sampai pada akhirnya timbul keinginan untuk membeli agar dapat dimilikinya. (Phillip Kotler, 2007:205) .

Pengertian Minat Beli Konsumen adalah sesuatu yang timbul setelah menerima rangsangan dari produk yang dilihatnya, dari sana timbul ketertarikan untuk mencoba produk tersebut sampai pada akhirnya timbul keinginan untuk membeli agar dapat dimilikinya. (Phillip Kotler, 205:2005). Menurut E. Jerome Mc. Carthy (2002:2980) minat beli merupakan dorongan yang timbul dalam diri seseorang untuk membeli barang atau jasa dalam rangka pemenuhan kebutuhannya. Tidak ada pembelian yang terjadi jika konsumen tidak pernah menyadari kebutuhan dan keinginannya

\section{Penelitian Terdahulu}

1. Penelitian yang dilakukan oleh Faradiba, S. (2013) mengenai Analisis Pengaruh Kualitas Produk, Harga, Lokasi dan Kualitas Pelayanan Terhadap Minat Beli Ulang Konsumen. Hasil penelitian ini menunjukkan bahwa secara umum kualitas produk, harga, lokasi dan kualitas pelayanan yang ada sudah baik. Semua hipotesis di dalam penelitian ini dapat diterima. Kelima variabel memiliki pengaruh positif terhadap minat beli ulang konsumen. Yang memiliki pengaruh paling tinggi adalah kualitas produk, kemudian diikuti lokasi, kualitas pelayanan dan harga. Didalam penelitian ini variabel terikat (minat beli ulang konsumen) dapat dijelaskan oleh variabel bebas ( kualitas produk, harga, lokasi, dan kualitas pelayanan) sebesar $49,8 \%$ dan $50,2 \%$ dijelaskan variabel bebas diluar penelitian ini.

2. Penelitian yang dilakukan oleh Kharisma, S. Arifin, Z \& Wilopo. (2014) mengenai Pengaruh International Brand Image Dan Kualitas Produk Terhadap Keputusan Pembelian. Hasil berupa adanya pengaruh signifikan secara simultan oleh kedua variabel bebas yang diteliti terhadap keputusan pembelian. Analisis secara parsial pada variabel international brand image memperoleh hasil yang tidak signifikan meskipun dengan nilai positif, artinya bahwa pengaruh yang ditimbulkan oleh international brand image hanya kecil atau tidak dapat dijadikan faktor utama untuk meningkatkan 
kepercayaan konsumen dalam pembelian. Uji parsial lain menunjukkan bahwa pengaruh yang dihasilkan oleh variabel kualitas produk memiliki hasil yang signifikan, artinya bahwa dengan meningkatkan kualitas pada produk maka meningkat pula kepercayaan konsumen untuk membeli produk.

3. Penelitian yang dilakukan oleh Pradipta, Hesti O \& Mashariono (2015), mengenai Pengaruh Citra Merek, Periklanan Terhadap Minat Beli Konsumen. Dari hasil penelitian bahwa variabel Citra Merek berpengaruh signifikan terhadap Minat Beli sebesar 7,546 dengan signifikasi 0,000 . Periklanan berpengaruh signifikan terhadap Minat Beli sebesar 3,374 dengan signifikasi 0,001 . Dengan demikian maka Citra Merek mempunyai pengaruh dominan terhadap Minat Beli Sehingga hipotesa yang dikemukakan terbukti signifikan kebenarannya.

4. Penelitian yang dilakukan oleh Mandasari (2017), mengenai Peran Produk, Harga, Dan Customer Service Dalam Membentuk Kepuasan Dan Loyalitas Pelanggan, Berdasarkan hasil analisis, produk dan customer service masih berpengaruh positif terhadap kepuasan pelanggan, namun harga berpengaruh negatif terhadap kepuasan pelanggan. Pengertian pengaruh negatif ini yaitu semakin murah harga, maka pelanggan semakin puas. Dibandingkan produk dan harga, customer service paling berpengaruh terhadap kepuasan pelanggan yaitu sebesar $79,59 \%$.
Kepuasan pelanggan memiliki pengaruh yang positif terhadap loyalitas pelanggan, yaitu sebesar $57,76 \%$. Di antara 3 variabel, customer service yang paling berpengaruh terhadap loyalitas pelanggan yaitu sebesar $73,10 \%$.

5. Penelitian yang dilakukan oleh Ningtias \& Budiarti (2017), mengenai Pengaruh Kualitas Pelayanan, Harga, Kepuasan Pelanggan Terhadap Loyalitas Pelanggan, hasil penelitian menunjukkan bahwa secara simutan variabel kualitas pelayanan, harga, dan kepuasan pelanggan mempunyai pengaruh terhadap loyalitas pelanggan, secara parsial menunjukkan bahwa variabel kualitas pelayanan berpengaruh positif dan signifikan terhadap loyalitas pelanggan dengan nilai signifikan sebesar 0,007 , Sedangkan variabel harga berpengaruh positif dan signifikan terhadap loyalitas pelanggan dengan nilai signifikan sebesar 0,011 , dan variabel kepuasan pelanggan berpengaruh positif dan signifikan terhadap loyalitas pelanggan dengan nilai signifikan 0,039 .

6. Penelitian oleh Susanti, D. (2017) mengenai Pengaruh Kualitas Produk Terhadap Minat Konsumen Dalam Membeli Produk. Variabel parsial Performance, Durability, Features yang secara signifikan mempengaruhi minat konsumen untuk membeli produk. Variabel Kesesuaian dengan specification and Reliability itu tidak secara signifikan mempengaruhi minat konsumen untuk membeli produk. Dari hasil uji analisis diketahui 
bahwa koefisien determinasi 0,362 atau $36,2 \%$ dari variasi variabel independen (Performance, Durability Features, Conformance to specification, and Reliability) terhadap variabel dependen (Consumer Interests in buying the product). Sedangkan sisanya $63,8 \%$ dijelaskan oleh variabel lain yang tidak termasuk dalam penelitian ini.

7. Penelitian oleh Zakaria, D \& Suwitho. (2017) mengenai Pengaruh Kualitas Pelayanan, Kualitas Produk Dan Harga Terhadap Kepuasan Pelanggan. Hasil pengujian menunjukkan bahwa variabel-variabel yang digunakan dalam model penelitian ini yaitu kualitas pelayanan, kualitas produk dan harga masing-masing mempunyai pengaruh signifikan dan positif terhadap kepuasan pelanggan Hasil ini mengindikasikan bahwa semakin baik kualitas pelayanan, kualitas produk, dan harga maka kepuasan pelanggan semakin meningkat.

\section{METODE PENELITIAN}

Penelitian deskriptif yang bertujuan untuk memperoleh deskripsi tentang ciriciri variabel dari objek yang diteliti yaitu Kualitas Produk, Harga, dan Minat Beli. Sedangkan penelitian Verifikatif menguji pengaruh kualitas produk dan harga terhadap minat beli pada lembur batik.

Untuk meneliti pengaruh kualitas produk dan harga terhadap minat beli konsumen pada Lembur Batik diperlukan data primer dan data sekunder yang diperoleh dengan cara wawancara, kuesioner, , Observasi serta Studi kepustakaan (Library Research)
Populasi dalam penelitian ini adalah para pembeli batik yang berjumlah 500 orang.

$$
\begin{aligned}
\mathrm{n} & =500 \\
\text { error } & =10 \% \\
& =0,1 \times 0,1 \times 500+1 \\
& =500 / 6 \\
\mathrm{~N} & =83.33=84
\end{aligned}
$$

Perhitungan sampel minimal disproportionate random sampling diketahui jumlah sampel minimal yang dibutuhkan adalah 84 orang. Dalam penelitian ini, ukuran sampel ditentukan oleh bentuk uji statistik.

Uji statistik yang akan digunakan dalam penelitian ini adalah analisis jalur (Path Analysis), yaitu meneliti hubungan diantara variabel penelitian kualitas produk, harga, dan minat beli pada lembur batik. Data tabulasi diolah dengan pendekatan analisis jalur (Path Analysis).

\section{ANALISIS DAN PERANCANGAN}

Tabel 1. Hasil Analisis Validitas Item Variabel $X_{1}$ (Kualitas Produk)

\begin{tabular}{cccccccc}
\hline $\mathbf{1}$ & $\mathbf{2}$ & $\mathbf{3}$ & $\mathbf{4}$ & $\mathbf{5}$ & $\mathbf{6}$ & $\mathbf{7}$ & $\mathbf{8}$ \\
\hline $\mathbf{0 , 6 8}$ & 0,68 & 0,46 & 0,68 & 0,70 & 0,76 & 0,77 & 0,78 \\
& & & & & & & \\
\hline Valid & Valid & Valid & Valid & Valid & Valid & Valid & Valid \\
& & & & & & & \\
\hline $\mathbf{9}$ & $\mathbf{1 0}$ & $\mathbf{1 1}$ & $\mathbf{1 2}$ & $\mathbf{1 3}$ & $\mathbf{1 4}$ & $\mathbf{1 5}$ & $\mathbf{1 6}$ \\
\hline $\mathbf{0 , 7 2}$ & 0,58 & 0,64 & 0,75 & 0,55 & 0,45 & 0,50 & 0,67 \\
\hline Valid & Valid & Valid & Valid & Valid & Valid & Valid & Valid
\end{tabular}

Tabel 2. Hasil Analisis Validitas Item Variabel $\mathrm{X}_{2}$ (Harga)

\begin{tabular}{cccccc}
\hline $\mathbf{1}$ & $\mathbf{2}$ & $\mathbf{3}$ & $\mathbf{4}$ & $\mathbf{5}$ & $\mathbf{6}$ \\
\hline $\mathbf{0 , 4 5 5}$ & 0,685 & 0,622 & 0,730 & 0,479 & 0,511 \\
\hline Valid & Valid & Valid & Valid & Valid & Valid \\
\hline
\end{tabular}

Sedangkan hasil uji validitas variabel Minat Beli $(Y)$ secara komprehensif dapat dilihat pada tabel di bawah ini : 
Tabel 3. Hasil Analisis Validitas Item Variabel Y (Minat Beli)

\begin{tabular}{cccccccc}
\hline 1 & 2 & 3 & 4 & 5 & 6 & 7 & 8 \\
\hline 0,6 & 0,6 & 0,6 & 0,6 & 0,7 & 0,7 & 0,6 & 0,6 \\
\hline Valid & Valid & Valid & Valid & Valid & Valid & Valid & Valid
\end{tabular}

Setiap item pertanyaan dikatakan valid apabila nilai $r$ hitung $>r$ tabel. Dengan nilai $r$ tabel $=0,3$ dan nilai $r$ hitung $>0,3$, maka pertanyaan tersebut valid.

Tabel 4. Hasil Uji Reliabilitas Instrument Variabel $\mathrm{X}_{1}, \mathrm{X}_{2}$, dan $\mathrm{Y}$

\begin{tabular}{llll}
\hline Variabel & $\mathbf{X}_{1}$ & $\mathbf{X}_{2}$ & $\mathbf{Y}$ \\
\hline Reliabilitas & 0.907 & 0.605 & 0.803 \\
\hline
\end{tabular}

Tabel 5. Matriks Korelasi Antar Variabel

\begin{tabular}{llll}
\hline Variabel & $\mathbf{X 1}$ & $\mathbf{X 2}$ & $\mathbf{Y}$ \\
\hline $\mathbf{X} 1$ & 1 & 0,354 & 0,671 \\
\hline $\mathbf{X} 2$ & 0,354 & 1 & \\
\hline $\mathbf{Y}$ & 0,671 & & 1 \\
\hline
\end{tabular}

Tabel 6. Matriks Korelasi Antar Variabel Bebas

\begin{tabular}{lll}
\hline Variabel & $\mathbf{X 1}$ & $\mathbf{X 2}$ \\
\hline $\mathbf{X 1}$ & 1 & 0,354 \\
\hline $\mathbf{X} 2$ & 0,354 & 1 \\
\hline
\end{tabular}

Tabel 7. Data Indikator Kualitas Produk

\begin{tabular}{clcc}
\hline $\mathbf{1}$ & $\begin{array}{l}\text { Jaminan kualitas } \\
\text { produk }\end{array}$ & $\mathbf{3 4 0}$ & Sangat Baik \\
\hline $\mathbf{2}$ & $\begin{array}{l}\text { Produk disukai } \\
\text { konsumen }\end{array}$ & 344 & Sangat Baik \\
\hline $\mathbf{3}$ & Desain setiap baju & 320 & Baik \\
\hline $\mathbf{4}$ & Jenis baju yang di jahit & 330 & Sangat Baik \\
\hline $\mathbf{5}$ & $\begin{array}{l}\text { Bahan baju yang } \\
\text { dipergunakan }\end{array}$ & 320 & Baik \\
\hline $\mathbf{6}$ & $\begin{array}{l}\text { Pengerjaan setiap } \\
\text { proses penjaitan. }\end{array}$ & 323 & Baik \\
\hline $\mathbf{7}$ & $\begin{array}{l}\text { Kesesuaian produk } \\
\text { dengan model yang } \\
\text { ditawarkan }\end{array}$ & 324 & Sesuai \\
\hline $\mathbf{8}$ & $\begin{array}{l}\text { Kesesuaian produk } \\
\text { dengan desain yang } \\
\text { diinginkan. }\end{array}$ & 317 & Sesuai \\
\hline $\mathbf{9}$ & Ketahanan produk & 308 & Baik \\
\hline $\mathbf{1 0}$ & Masa garansi produk & 297 & Cukup \\
\hline $\mathbf{1 1}$ & Pengenalan produk & 307 & Baik
\end{tabular}

\begin{tabular}{llcl}
\hline 12 & Pemahaman produk & 294 & Cukup \\
\hline 13 & Gaya baju yang unik & 286 & Cukup \\
\hline 14 & Kondisi baju & 293 & Cukup \\
\hline 15 & Model produk & 276 & Cukup \\
\hline 16 & Harga & 262 & Cukup
\end{tabular}

Tabel 8. Data Indikator Harga

\begin{tabular}{clcc}
\hline No & $\begin{array}{l}\text { Pernyataan } \\
\text { Harga yang } \\
\text { mahal }\end{array}$ & Skor & $\begin{array}{c}\text { Keterangan } \\
\text { Cukup } \\
\text { Mahal }\end{array}$ \\
\hline $\mathbf{2}$ & Harga pasar & 354 & $\begin{array}{c}\text { Sangat } \\
\text { Sesuai }\end{array}$ \\
\hline $\mathbf{3}$ & $\begin{array}{l}\text { Harga sesuai } \\
\text { permintaan } \\
\text { pasar }\end{array}$ & 365 & $\begin{array}{c}\text { Sangat } \\
\text { Sesuai }\end{array}$ \\
\hline $\mathbf{4}$ & $\begin{array}{l}\text { Harga sesuai } \\
\text { kepentingan } \\
\text { pasar }\end{array}$ & 358 & $\begin{array}{l}\text { Sangat } \\
\text { Sesuai }\end{array}$ \\
\hline $\mathbf{5}$ & $\begin{array}{l}\text { Harga sama } \\
\text { dengan pesaing }\end{array}$ & 366 & $\begin{array}{c}\text { Sangat } \\
\text { Bersaing } \\
\text { Sangat } \\
\text { Berbeda }\end{array}$ \\
\hline $\mathbf{6}$ & $\begin{array}{l}\text { Harga tidak } \\
\text { sama dengan } \\
\text { pesaing }\end{array}$ & 348 & \\
\hline
\end{tabular}

Tabel 9. Data Indikator Minat

\begin{tabular}{clcc}
\hline No & \multicolumn{1}{c}{ Pernyataan } & Skor & Ket. \\
\hline $\mathbf{1}$ & Jenis Produk & 335 & Sangat Baik \\
\hline $\mathbf{2}$ & Bentuk produk & 337 & Sangat Baik \\
\hline $\mathbf{3}$ & Melakukan pembelian & 334 & Sering Membeli \\
\hline $\mathbf{4}$ & Melakukan penawaran & 352 & Sering Menawar \\
\hline $\mathbf{5}$ & Melakukan jual beli & 337 & Sering Transaksi \\
\hline $\mathbf{6}$ & Melakukan kunjungan & 344 & Sering Berkunjung \\
\hline $\mathbf{7}$ & Keputusan bertransaksi & 346 & Sangat Tinggi \\
\hline $\mathbf{8}$ & Keputusan berkunjung & 302 & Cukup Tinggi \\
\hline
\end{tabular}

\section{HASIL DAN PEMBAHASAN}

Tabel 10. Hasil SPSS

\begin{tabular}{|c|c|c|c|c|c|c|}
\hline & \multicolumn{6}{|c|}{ Coefficients $^{a}$} \\
\hline & & \multirow{2}{*}{\multicolumn{2}{|c|}{$\begin{array}{l}\text { Unstandardized } \\
\text { Coefficients }\end{array}$}} & \multirow{2}{*}{\multicolumn{2}{|c|}{$\begin{array}{l}\text { Standardized } \\
\text { Coefficients }\end{array}$}} & \\
\hline & & & & & & \\
\hline & Model _- & B & Std.error & Beta & $\mathrm{t}$ & Sig. \\
\hline 1 & (Constant) & 5.762 & 3.784 & & 1.523 & .132 \\
\hline & kualitas_produk & .242 & .035 & .577 & 6.943 & .000 \\
\hline & harga & .495 & .156 & .263 & 3.163 & .002 \\
\hline a. & Dependent Variabe & minat & & & & \\
\hline
\end{tabular}


Tabel 11. Nilai Koefisien Jalur

\begin{tabular}{ccc}
\hline $\begin{array}{c}\text { Koefisien } \\
\text { Jalur }\end{array}$ & $\begin{array}{c}\text { Nilai } \\
\text { Koefisien } \\
\text { Jalur }\end{array}$ & Kesimpulan \\
\hline Py, X1 & 0,577 & $\begin{array}{c}\text { Terdapat pengaruh } \\
\text { Kualitas Produk } \\
\text { terhadap Minat Beli }\end{array}$ \\
\hline Py, X2 & 0,263 & $\begin{array}{c}\text { Terdapat pengaruh } \\
\text { Harga terhadap } \\
\text { Minat Beli }\end{array}$
\end{tabular}

Hasil perhitungan di atas menunjukkan bahwa koefisien jalur secara parsial antara Kualitas Produk $\left(X_{1}\right)$ dengan Minat Beli $(Y)$ sebesar 0,577, Harga $\left(X_{2}\right)$ dengan Minat Beli $(Y)$ sebesar 0,263. Pengujian hipotesis tersebut dilakukan melalui statistik uji $F$, dengan ketentuan tolak $\mathrm{H}_{0}$ jika $F_{\text {hitung }}>$ Ftabel dan sebaliknya terima $\mathrm{H}_{0}$ jika Fhitung $<F_{\text {tabel. }}$ Dari perhitungan diperoleh hasil sebagai berikut : $F=$ Dari tabel $\mathrm{F}$ untuk tingkat signifikansi 0,05 dan derajat bebas $\mathrm{db}_{1}=2$ dan $\mathrm{db}_{2}=84-2-1=81$, diperoleh $\mathrm{F}_{0,05(2 ; 47)}=3,1075$.

Tabel 12. Pengujian secara simultan

\begin{tabular}{|c|c|c|c|c|}
\hline $\begin{array}{l}\text { Hipotesis } \\
\text { Alternatif }\end{array}$ & $\begin{array}{l}F \\
\text { hitung }\end{array}$ & $\begin{array}{l}F \\
\text { tabel }\end{array}$ & Keputusan & Kesimpulan \\
\hline $\begin{array}{l}\text { X1 dan } X 2 \\
\text { secara } \\
\text { simultan } \\
\text { berpengaruh } \\
\text { terhadap } Y\end{array}$ & 42.180 & 3,10 & Ho ditolak & Signifikan \\
\hline
\end{tabular}

Karena $F_{\text {hitung }}>F_{\text {tabel }}$ maka $\mathrm{H}_{0}$ ditolak pada tingkat signifikansi 0,05 . Berdasarkan pada hasil pengujian dapat disimpulkan terdapat pengaruh yang signifikan (nyata) antara Kualitas Produk $\left(X_{1}\right)$ dan Harga $\left(X_{2}\right)$ secara bersamasama terhadap Minat Beli (Y).

$\mathrm{H}_{0}: \rho_{\mathrm{yxi}}=0$ (Tidak terdapat pengaruh Kualitas Produk \& Harga terhadap Minat Beli).

$\mathrm{H}_{1}: \rho_{y x i} \neq 0$ (Terdapat pengaruh Kualitas Produk \& Harga terhadap Minat Beli ). (untuk i = 1 dan 2)

Selanjutnya nilai tersebut dibandingkan dengan nilai tabel untuk $\mathrm{n}=84$ dengan taraf kesalahan $5 \%$ dan $\mathrm{db}=\mathrm{n}-\mathrm{k}-1=84-$ 2-1 adalah 1,658.

Tabel 13. Hasil Uji Parsial

\begin{tabular}{lllllll}
\hline No & Hipotesis Koefisien & thitung ttabel & Keputusan Kesimpulan \\
jalur
\end{tabular}

Hipotesis penelitian pertama (1) dikemukakan bahwa "Kualitas Produk berpengaruh terhadap Minat Beli". Berdasarkan hasil uji statistik dengan uji $\mathrm{t}$ diperoleh thitung $=6,943>t_{\text {tabel }}=1,658$, sehingga $\mathrm{H}_{0}$ ditolak, yang berarti Kualitas Produk berpengaruh terhadap Minat Beli.

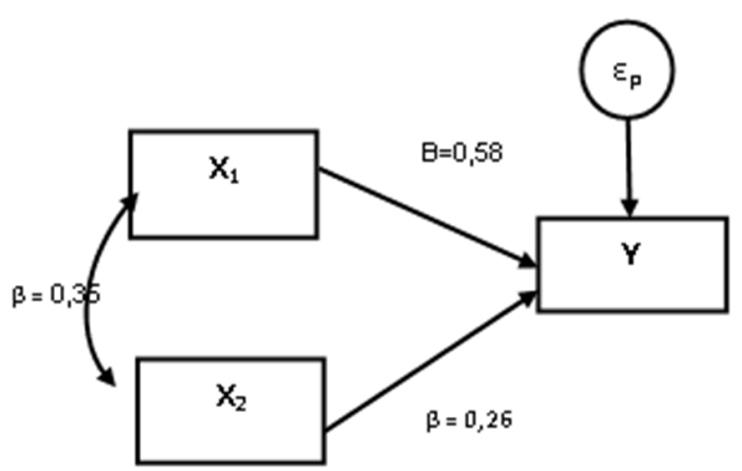

Hipotesis penelitian kedua (2) dikemukakan bahwa "Harga berpengaruh terhadap Minat Beli". Berdasarkan hasil uji statistik dengan uji $\mathrm{t}$ diperoleh thitung $=3,163>\mathrm{t}_{\text {tabel }}=1,658$; sehingga $\mathrm{H}_{0}$ ditolak, yang berarti Harga berpengaruh terhadap Minat Beli.

\section{Pengaruh Kualitas Produk Terhadap Minat Beli}

Besar pengaruh langsung kualitas produk $\left(\mathrm{X}_{1}\right)$ terhadap minat beli $(\mathrm{Y})$ adalah $33,29 \%$ dan pengaruh tidak langsung kualitas produk ( $\left.\mathrm{X}_{1}\right)$ terhadap minat beli $(\mathrm{Y})$ yang melalui harga $\left(\mathrm{X}_{2}\right)$ 
adalah 5,37\%. Total Pengaruh baik langsung maupun tidak langsung kualitas produk $\left(\mathrm{X}_{1}\right)$ terhadap minat beli (Y) adalah $38,66 \%$. Hal ini memiliki arti bahwa semakin baik kualitas produk $\left(\mathrm{X}_{1}\right)$ maka semakin baik pula minat beli di Lembur Batik. Menurut Susanti (2017:23) kualitas merupakan salah satu syarat yang menumbuhkan minat beli dari konsumen. Menurut Susanti (2017:230) produk dapat dianggap berkualitas jika dapat memenuhi harapan pelanggan. Kualitas produk harus memiliki nilai lebih dan berbeda dari produk lainnya yang di tawarkan oleh penjual kepada pembeli seperti halnya jaminan kualitas, model, desain dan sikap suka yang dimiliki pembeli tersebut. Meskipun ada beberapa faktor lainya seperti bahan, proses produksi, tingkat kesesuaian, pengenalan, kecocokan, daya tahan dan harga produk semua itu merupakan unsurunsur pelengkap yang saling berkaitan satu sama lainnya. Menurut Philip Kotler (2007:94) menjelaskan salah satu nilai utama yang diharapkan oleh pelanggan dari pemasok adalah mutu produk dan jasa yang tinggi. Maka dari pernyataan tersebut dapat dinyatakan bahwa mutu atau kualitas produk dapat mempengaruhi konsumen dalam memutuskan untuk memperoleh produk tersebut.

\section{Pengaruh Harga Terhadap Minat Beli}

Besar pengaruh langsung harga $\left(\mathrm{X}_{2}\right)$ terhadap minat beli $(\mathrm{Y})$ adalah $6,92 \%$ dan pengaruh tidak langsung harga $\left(\mathrm{X}_{2}\right)$ terhadap minat beli $(\mathrm{Y})$ yang melalui kualitas produk $\left(\mathrm{X}_{1}\right)$ adalah $5,37 \%$. Total Pengaruh baik langsung maupun tidak langsung harga $\left(\mathrm{X}_{2}\right)$ terhadap minat beli (Y) adalah 12,29\%. Hal ini memiliki arti bahwa semakin baik harga $\left(\mathrm{X}_{2}\right)$ maka semakin baik pula minat beli di Lembur Batik. Harga adalah sejumlah uang sebagai alat tukar untuk memperoleh produk atau jasa. Harga dapat juga dikatakan penentuan nilai suatu produk dibenak konsumen, Djaslim Saladin (2007:95). Menurut Ningtias dan Budiarti (2017: 3) Harga adalah nilai tukar yang disamakan dengan uang atau barang lain untuk manfaat yang diperoleh dari barang atau jasadan sejumlah uang yang konsumen bayar untuk produk tertentu. Penetapan harga yang tepat sesuai dengan kebutuhan pasar harus peka dan fleksibel dalam memahami keadaan dan perkembangan yang ada seperti bahwa harga sesuai dengan kepentingan ,perkembangan dan permintaan pasar serta memiliki daya saing yang kuat dimana hal ini dapat menumbuhkan minat beli seseorang terhadap suatu produk. Harga dapat diubah dengan cepat tidak seperti produk dan distribusi. Penetapan dan persaingan harga merupakan masalah nomor satu yang dihadapi perusahaan. Banyak perusahaan yang tidak menangani penetapan harga yang baik, Kotler (2007:519).

Tabel 14. Pengaruh Masing-masing Variabel $X$ terhadap $Y$

\begin{tabular}{|l|c|}
\hline $\begin{array}{c}\text { Pengaruh langsung dan tidak } \\
\text { langsung }\end{array}$ & $\begin{array}{c}\text { Besar } \\
\text { kontribusi }\end{array}$ \\
\hline X1 langsung & $33,29 \%$ \\
\hline X1 tidak langsung & $5,37 \%$ \\
\hline Total pengaruh $x 1$ terhadap y & $38,66 \%$ \\
\hline
\end{tabular}

\begin{tabular}{|l|c|}
\hline \multicolumn{1}{|c|}{$\begin{array}{c}\text { Pengaruh langsung dan tidak } \\
\text { langsung }\end{array}$} & $\begin{array}{c}\text { Besar } \\
\text { kontribusi }\end{array}$ \\
\hline X2 langsung & $6,92 \%$ \\
\hline X2 tidak langsung & $5,37 \%$ \\
\hline Total pengaruh $\mathrm{x}$ 2 terhadap y & $12,29 \%$ \\
\hline
\end{tabular}

Hasil pengujian secara bersamasama menunjukkan ketiga variabel yaitu : kualitas produk $\left(\mathrm{X}_{1}\right)$ dan harga $\left(\mathrm{X}_{2}\right)$ secara bersama-sama berpengaruh terhadap Minat Beli (Y), dengan besarnya pengaruh yaitu $50,95 \%$ dan sisanya $49,05 \%$ dipengaruhi oleh faktor 
lain yang tidak diamati dalam penelitian ini. Hasil penelitian menunjukkan bahwa pada Minat Beli di Lembur Batik dipengaruhi secara nyata oleh variabel kualitas produk dan harga.

Berdasarkan hasil analisis di atas diperoleh gambaran bahwa minat beli di Lembur Batik ternyata tidak hanya dipengaruhi oleh kualitas produk dan harga saja. Melainkan dipengaruhi juga oleh faktor-faktor lain. Dari hasil perhitungan koefisien determinasi di dapat nilai $\mathrm{R}^{2}$ sebesar $51 \%$ artinya pengaruh atau kontribusi dari kualitas produk dan harga sebesar $51 \%$ terhadap minat beli di Lembur Batik sedangkan sisanya sebesar $49 \%$ dipengaruhi oleh faktor atau variabel lain sehingga secara simultan Kualitas Produk dan Harga berpengaruh terhadap Minat Beli dan secara parsial Kualitas Produk lebih dominan dibandingkan dengan Harga terhadap Minat Beli di Lembur batik. Dilakukan secara bersama-sama diharapkan dapat meningkatkan minat beli yang lebih baik lagi.

\section{PENUTUP}

Lembur Batik secara umum memiliki kualitas produk yang baik dan merupakan jenis produk yang disukai oleh konsumen. Namun terdapat beberapa produk yang harus di tingkatkan kualitasnya seperti model, desain, bahan, daya tahan dan beberapa harga yang masih kurang cocok dengan selera konsumen serta kurangnya informasi mengenai garansi produk, pengenalan produk dan pemahaman produk. Lembur Batik memiliki harga yang baik sesuai dengan permintaan dan kepentingan pasar. Namun masih ada sebagian produk dengan harga yang masih sangat mahal diatas harga pasaran.
Minat beli konsumen pada lembur batik sangat baik dimana konsumen sangat berminat untuk melakukan penawaran, meskipun minat konsumen untuk melakukan kunjungan ke lembur batik kurang maksimal.

Dari hasil penelitian diketahui bahwa secara simultan kualitas produk dan harga berpengaruh terhadap minat beli di lembur batik dan secara parsial kualitas produk lebih dominan berpengaruh terhadap minat beli dibandingkan dengan harga batik pada lembur batik.

Diharapkan ada penelitian lanjutan oleh peneliti lain mengenai permasalahan pengalaman , pelanggan dan kepuasan pelanggan serta faktorfaktor yang mempengaruhi minat beli selain kualitas produk dan harga.

\section{DAFTAR PUSTAKA}

Alma, Buchory. (2007). Manajemen Pemasaran dan Pemasaran Jasa.Bandung: Alfabeta.

Buchory dan Saladin. (2010). Manajemen Pemasaran . Bandung: Linda Karya.

Edward \& Wang, Shih-Tse.(2013). The Influence of Visual Packaging Design on Perceived Food Product Quality, Value, and Brand Preference. International Journal of Retail \& Distribution Management.41,805-816.

Fakultas Ekonomi Unwim. (2013). Pedoman Penulisan Skripsi Fakultas Ekonomi Universitas Winaya Mukti": Bandung.

Fanny, Ben Lowe Chan. Yee, Fong. \& Yeow, Pamela. (2014).Price Promotions and Their Effect Upon 
Reference Prices. Journal of Product \& Brand Management, $23,349-361$

Faradiba, S. (2013). Analisis Pengaruh Kualitas Produk, Harga, Lokasi dan Kualitas Pelayanan Terhadap Minat Beli Ulang Konsumen. Diponogoro Journal Of Management, 2, 1-11.

Hurriyati. (2010). Bauran Pemasaran dan Loylitas Konsumen.Bandung : Alfabeta

Indriantoro. Nur. dan Supomo. (2008). Metodologi Penelitian Bisnis, Jogjakarta:BPFE.

Indrawati. (2015). Metode Penelitian Manajemen dan Bisnis. Bandung: Refika Aditama.

Kharisma, S. Arifin, Z. \& Wilopo. (2014) Pengaruh International Brand Image Dan Kualitas Produk Terhadap Keputusan Pembelian. Jurnal Administrasi Bisnis.14, 9197.

Kotler,Phillip.\&Amstrong. (2007). Dasardasar Pemasaran. Jakarta: PT. Indeks Gramedia.

Kotler,Phillip.\&Keller.(2009). Manajemen Pemasaran. Jakarta: Macanan Jaya Cemerlang.

Kotler,Phillip.\&Keller.(2008). Manajemen Pemasaran. Jakarta: Erlangga.

Kotler,Phillip.\&Keller.(2007). Manajemen Pemasaran. Jakarta :Indeks Gramedia.
Leonidas, C. \& Leonidou. (2005). Industrial Buyers' Influence Strategies: Buying Situation Differences. Journal of Business \& Industrial Marketing, 20 , $33-42$.

Mandasari, Andini E. (2017). Peran Produk, Harga, Dan Customer Service Dalam Membentuk Kepuasan Dan Loyalitas Pelanggan Kartu Pascabayar. Jurnal Ekonomi Manajemen, 3,50 -58 .

Mursid. (2010). Manajemen Pemasaran. Jakarta: Bumi Aksara.

Mundir. (2013). Statistik Pendidikan. Jogjakarta: Pustaka Pelajar.

Nembah. (2011). Manajemen Pemasaran. Bandung: Yrama Widya.

Ningtias. Anaisaa, A dan Budiarti, A. (2017) Pengaruh Kualitas Pelayanan, Harga, Kepuasan Pelanggan Terhadap Loyalitas Pelanggan Bimbingan Belajar Alfagama Surabaya. Jurnal Ilmu Riset dan Manajemen. 6 ,1-16.

Paswan, Audhesh. \& Ganesh, K Gopala (2003). Familiarity and interest: in a learning center service context. Journal of Services Marketing, 17,393-419.

Pradipta. Hesti, O. \& Mashariono. (2015) Pengaruh Citra Merek, Periklanan Terhadap Minat Beli Konsumen Thermometer Onemed Di Surabaya. Jurnal Ilmu dan Riset Manajemen, 4, 1-19. 
Sugiyono. (2017). Metode

Penelitian.Bandung : Alfabeta.

Sugiama. (2008). Metode Riset Bisnis dan Manajemen.Bandung:Guardaya Intimarta

Susanti, D. (2017). Pengaruh Kualitas Produk Terhadap Minat Konsumen Dalam Membeli Produk Tupperware Pada Perumahan Griya Tika Utama. Pekanbaru: Menara Ekonomi . 3, 23-32.

Tjiptono. (2007). Total Quality Manajemen. Malang:Bayu Media Publishing.

Zakaria, D. \& Suwitho. (2017) Pengaruh Kualitas Pelayanan, Kualitas Produk Dan Harga Terhadap Kepuasan Pelanggan. Jurnal Ilmu dan Riset Manajemen. 6,1-18. 